\title{
SOLAR CONCENTRATORS IN MALAYSIA: TOWARDS THE DEVELOPMENT OF LOW COST SOLAR PHOTOVOLTAIC SYSTEMS
}

\author{
FIRDAUS MUHAMMAD-SUKKI ${ }^{*}$, ROBERTO RAMIREZ-INIGUEZ ${ }^{2}$, \\ SCOTT G. MCMEEKIN ${ }^{3}$, BRIAN G. STEWART ${ }^{4} \&$ BARRY CLIVE $^{5}$
}

\begin{abstract}
Solar energy has become a matter of global attention in the past few years. This paper explores the use and benefit of solar concentrators in the solar photovoltaic (PV) systems. First, a short literature review of previous research on the usage of solar concentrators in improving solar PV system performance and reducing the cost of implementation is presented. This is followed by an overview of SolarBrane, an example of a Building Integrated photovoltaic (BIPV) system which uses an optical concentrator in the solar PV design. An optimised design of the SolarBrane is also discussed afterwards. A financial benefit study is conducted to compare the average return of investment of using the optimised SolarBrane and traditional solar PV installed in Malaysia's environment. SolarBrane has proven to be a good alternative to achieve costeffective solar PV system. The financial analysis simulated under the new Malaysian Feed-In Tariff scheme indicates that the optimised SolarBrane could potentially reduce the initial cost of implementation by $40 \%$ and generate higher return, close to $20 \%$, when compared to traditional solar PV systems.
\end{abstract}

Keywords: Solar photovoltaic; solar concentrator; solarBrane; dielectric totally internally reflecting concentrator; financial analysis

\subsection{INTRODUCTION}

Malaysia receives a high level of solar insolation, ranging from 1,400 to $1,900 \mathrm{kWh} / \mathrm{m}^{2}$ [1], averaging about $1,643 \mathrm{kWh} / \mathrm{m}^{2}$ per year [2] with more than 10 sun hours per day [3]. Given this potential, it is inevitable that future energy technologies will tap into this resource for the benefit of Malaysia's population. One of the solar energy applications which is widely used in harnessing solar

1-4 School of Engineering and Computing, Glasgow Caledonian University, Cowcaddens Road, Glasgow, G4 0BA, Scotland, United Kingdom

Solar Empower Ltd, 74-75 Brunner Road, London, E17 7NW, England, United Kingdom

* Corresponding author: firdaus.muhammadsukki@gcu.ac 
energy is solar photovoltaic (PV), through which the sunlight is converted into electricity.

Since the $6^{\text {th }}$ Malaysia Plan, a significant amount of money has been spent on research and development (R\&D) activities related to solar technologies [4], [5], [6]. It is reported that by April 2010, approximately MYR157 million had been awarded to green technology research, including solar research, under the $9^{\text {th }}$ Malaysia Plan [6]. The Malaysian Government has also introduced a number of policies that have helped to accelerate the use of solar technology in Malaysia [7],[8],[9], but the installation of solar PV only started to soar during the Malaysia Building Integrated Photovoltaic Technology Application Project (MBIPV Project) which was launched on the 25th July 2005 [10]. The main objective of this programme was to reduce the long-term cost of BIPV technology in Malaysia, which later should lead to an increase in BIPV technology applications whilst reducing emissions of green house gas within the country. This project ended on the 31st December 2010, with a total capacity successfully installed and commissioned of $1,516.00 \mathrm{kWp}$, covering 109 buildings. The cost of PV also reduced greatly from MYR31,410.00 per $\mathrm{kWp}$ in December 2005 to MYR19,120.00 per kWp in March 2010, a reduction of about 40\% of the cost [10].

However, despite numerous efforts undertaken by the government, solar energy only contributes to less than 1\% of Malaysia's energy demand [11]. Some of the main drawbacks of solar technology are related to the high investment cost and long payback period [1], [9]. Current installation costs of a simple solar PV system indicate that around $60 \%$ of the total cost comes from the PV module [10]. A recent survey conducted by Haw et al. [12] suggested that most Malaysians only consider installing a solar PV if the cost of a solar panel is below MYR5,500.00 per $\mathrm{kW}$, about $30 \%$ of the present market price. Furthermore, the International Energy Agency (IEA) projected that the PV cell price will only reduce to about $50 \%$ in 2020 (when compared to the pricing in 2008), which is more than a decade from now [13].

Solar concentrators are perhaps the most favourable solution to this problem $[14]$ and this is presented in the next section.

\subsection{SOLAR CONCENTRATOR IN MALAYSIA}

A solar concentrator is a device that allows the collection of sunlight from a large area and redirects it to a smaller receiver or exit [15]. For the past four decades, there have been many developments related to the design of solar concentrators. Some of the designs are: parabolic concentrator, hyperboloid concentrator, Fresnel lens concentrator, compound parabolic concentrator (CPC), dielectric 
totally internally reflecting concentrator (DTIRC), flat high concentration devices and quantum dot concentrator (QDC) [15]. A conceptual representation of a solar concentrator used in harnessing the power from the sun to generate electricity is shown in Figure 1.
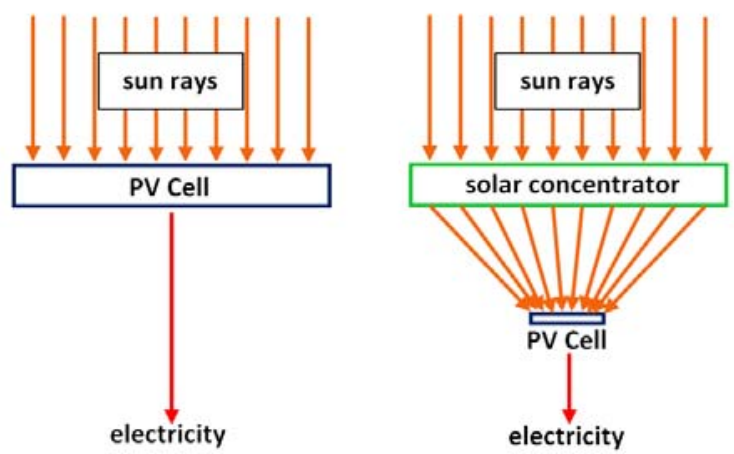

Figure 1 Generating electricity from the sun, with and without a solar concentrator [15]

The material used to fabricate a concentrator varies depending on the application. For solar thermal, most of the concentrators are made from mirrors while for BIPV systems, the concentrator is either made of glass or transparent plastic. These materials are far cheaper than PV material. The cost per unit area of a solar concentrator is therefore much cheaper than the cost per unit area of PV cell material. By introducing a concentrator, not only could the same amount of energy be collected from the sun, but the total cost of the solar cell can also be reduced. Arizona Public Service has concluded that the most cost-effective PV modules for commercial applications in the future will be dominated by high concentration collectors incorporated with high-efficiency cells [16]. Some of the advantages and disadvantages of using solar concentrators are summarise in Table 1 .

Table 1 Advantages and disadvantages of using solar concentrators

\begin{tabular}{ll}
\hline Description & Reference \\
\hline Advantage & \\
Reduce the dependency on silicon cell & {$[17],[18],[19]$} \\
Increase the intensity of solar irradiance, hence increase the cell efficiency & {$[17],[18]$} \\
Reduce the total cost of the whole system & {$[17],[18][18]$} \\
\hline Disadvantage & \\
Degrade the PV cell lifespan & {$[20]$} \\
Might require mechanical tracking system & {$[21],[22],[23]$} \\
Need to cool down the PV to ensure the performance of the PV is optimum & {$[24],[25]$} \\
\hline
\end{tabular}


Table 2 R\&D activities related to solar concentrator in Malaysia

\begin{tabular}{|c|c|c|c|c|c|}
\hline Name & $\begin{array}{c}\text { Concentrator } \\
\text { Type }\end{array}$ & $\begin{array}{l}\text { Focus } \\
\text { (Point/ } \\
\text { Linear) }\end{array}$ & $\begin{array}{c}\text { Sun } \\
\text { Concentration }(\mathrm{X}) \\
1 \mathrm{X}=1000 \mathrm{~W} / \mathrm{m}^{2}\end{array}$ & $\begin{array}{c}\text { Tracking } \\
\text { (Yes/ } \\
\text { No) }\end{array}$ & Ref. \\
\hline $\begin{array}{c}\text { Universiti } \\
\text { Teknologi } \\
\text { PETRONAS/ } \\
\text { Universiti Sains } \\
\text { Malaysia }\end{array}$ & $\begin{array}{l}\text { Cylindrical } \\
\text { parabolic trough } \\
\text { concentrator }\end{array}$ & Linear & 200 & No & [26] \\
\hline $\begin{array}{l}\text { Universiti Tunku } \\
\text { Abdul Rahman }\end{array}$ & $\begin{array}{l}\text { Non-Imaging } \\
\text { Planar } \\
\text { Concentrator }\end{array}$ & $\mathrm{n} / \mathrm{a}$ & 336 to 422 & No & [27] \\
\hline $\begin{array}{c}\text { Universiti } \\
\text { Teknologi } \\
\text { Malaysia }\end{array}$ & Heliostat & Point & $\mathrm{n} / \mathrm{a}$ & Yes & [28] \\
\hline $\begin{array}{l}\text { Kolej Universiti } \\
\text { Kejuruteraan } \\
\text { Utara Malaysia }\end{array}$ & Heliostat & Point & $\mathrm{n} / \mathrm{a}$ & Yes & [29] \\
\hline $\begin{array}{c}\text { Universiti Putra } \\
\text { Malaysia }\end{array}$ & Parabolic Dish & Point & $\mathrm{n} / \mathrm{a}$ & Yes & [30] \\
\hline $\begin{array}{c}\text { Universiti Tenaga } \\
\text { Nasional }\end{array}$ & Square Mirror & $\mathrm{n} / \mathrm{a}$ & $\mathrm{n} / \mathrm{a}$ & Yes & [31] \\
\hline $\begin{array}{l}\text { Universiti Islam } \\
\text { Antarabangsa }\end{array}$ & $\begin{array}{l}\text { Compound } \\
\text { Parabolic } \\
\text { Concentrator }\end{array}$ & Point & $\mathrm{n} / \mathrm{a}$ & Yes & [32] \\
\hline Universiti Malaya & $\begin{array}{l}\text { Luminescent } \\
\text { Solar } \\
\text { Concentrator }\end{array}$ & $\mathrm{n} / \mathrm{a}$ & $\mathrm{n} / \mathrm{a}$ & No & [33] \\
\hline $\begin{array}{l}\text { Universiti Tunku } \\
\text { Abdul Rahman }\end{array}$ & $\begin{array}{l}\text { Luminescent } \\
\text { Solar } \\
\text { Concentrator }\end{array}$ & $\mathrm{n} / \mathrm{a}$ & $\mathrm{n} / \mathrm{a}$ & No & [34] \\
\hline
\end{tabular}

Until 2010, there were limited research and development (R\&D) activities related to the use of optical concentrator in the PV module design. Table 2 indicates some of these R\&D activities conducted in Malaysia. Looking at Table 2, there are some interesting points that can be highlighted, as follows:

(i) The research related to solar concentrator in the PV module was conducted only by the universities; there were no contribution from the government research institute or the private $R \& D$ companies. It is possible to say that since solar energy is a relatively new field, most of the R\&D activities conducted are considered as basic research [4].

(ii) Solar tracking systems are incorporated in some of the designs. Although it is possible to increase the efficiency and performance of the solar PV, the tracking system is considered expensive [35] and 
consumes more power for mechanical movement. Hence it will offset the electricity generated from the solar PV system itself [36][37].

(iii) Most of the designs in (ii) use a small area of PV cell, which helps to cut the dependency on large areas of expensive silicon. However, due to its mounting structure, the combined design of the concentrator and the solar tracker is only suitable for a flat roof type of house and commercial building. Hence it is not suitable and not desirable for the implementation on an inclined roof of a house or building facade.

It is desirable to implement a solar PV system that: (i) incorporates a solar concentrator which not only maintains or provides better performance than a traditional solar PV system, and (ii) is cost effective. A good example of a solar PV that fits these criteria is the SolarBrane.

\subsection{SOLARBRANE}

SolarBrane is a Building Integrated Photovoltaic (BIPV) system developed by SolarEmpower Ltd [18]. This static solar device is made from an array of small components known as the Solar Photonics Optoelectronics Transformer (SPOT). Each SPOT module (which comprises of an optical concentrator and a PV cell) in the system is cooled by water or air, depending on its application. To ensure that the SolarBrane is cost competitive without compromising its performance, an optical concentrator is incorporated in the SPOT design, as illustrated in Figure 2. A SPOT utilizes an extrusion of a dielectric totally internally reflecting concentrator (DTIRC) based on the phase conserving method (PCM). The DTIRC offers two advantages when compared with the other type of concentrators: higher concentrations and compact sizes [38].

SolarBrane utilises only $30 \%$ of the PV cell when compared to the traditional solar PV system, but the optical concentrator allows an increase in terms of geometrical gain of about 4.5 depending on the DTIRC design [39]. All the rays within the acceptance angle of the DTIRC are directed to the PV cell after a single internal reflection, enabling the SolarBrane to generate more electricity than a conventional solar PV system. Outside the acceptance angle, the rays pass through the side profiles of the concentrator to produce natural illumination to the building [39]. 


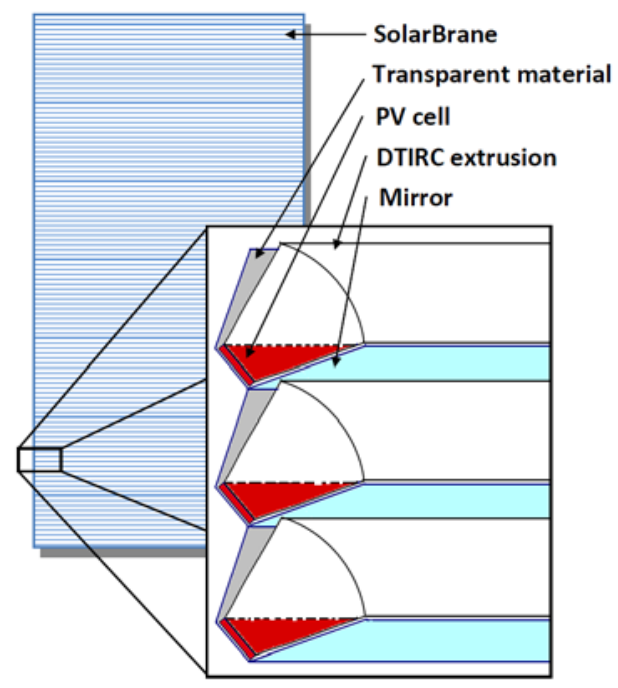

Figure 2 SolarBrane design [39],[41]

To ensure that the system is working at an optimum level, it is cooled either by water or air. Cooling using water is carried out by attaching a pipe at the bottom of the PV cell, where the heated water is collected and could be used as hot water and space heating application [39]. Cooling by air is achieved by combining the laminar flow effect and the chimney effect, creating good air ventilation for the house [39]. These processes allows SolarBrane not only to generate electricity, but also the capability of producing hot water, space heating, ventilation and illumination, which further reduces the electricity requirement in a building, making it more desirable [18],[39].

Recently, an optimised design of the SolarBrane has been proposed to further improve its performance. The optimised design is a DTIRC based on the maximum concentration method (MCM) [40]. A DTIRC based on the MCM is created by imposing a condition such that all the rays within the acceptance angle experience a single total internal reflection at the sidewall of the concentrator and arrive at the exit aperture (where the solar cell is attached), without restricting the exit angle and the incident angle, which results in achieving the maximum possible concentration. The general properties of the MCM are presented in details in [41].

The comparative geometrical performance of the MCM and PCM is presented in [40],[41],[42]. From MATLAB simulations, it has been shown that the MCM offers higher geometrical concentration gains than the PCM, at the cost of increasing the concentrator size [40]. Table 3 illustrates one of the comparative analyses of implementing the MCM, by varying the front surface arc angle of the 
DTIRC. Here, it can be seen that the geometrical concentration gain is increased to between $0.22 \%$ and $2.77 \%$ while the entrance diameter and the total height are increased from $0.18 \%$ to $2.31 \%$ and from $0.22 \%$ to $2.77 \%$ respectively.

Table 3 Comparison of Geometrical Concentration Gain vs Arc Angle (Index of Refraction=1.5, Acceptance Angle $=20^{\circ}$, Exit Aperture $=1 \mathrm{~cm}$,

Number of Coordinate's Precision $=200$ )

\begin{tabular}{|c|c|c|c|c|c|c|c|c|c|}
\hline \multirow{2}{*}{$\begin{array}{c}\text { Arc } \\
\text { Angle } \\
\left(^{\circ}\right)\end{array}$} & \multicolumn{3}{|c|}{$\begin{array}{c}\text { Phase } \\
\text { Conserving } \\
\text { Method } \\
\end{array}$} & \multicolumn{3}{|c|}{$\begin{array}{c}\text { Maximum } \\
\text { Concentration } \\
\text { Method } \\
\end{array}$} & \multicolumn{3}{|c|}{$\begin{array}{c}\text { Percentage of Change } \\
(\%)\end{array}$} \\
\hline & $\begin{array}{l}\text { Entrance } \\
\text { diameter } \\
(\mathrm{cm})\end{array}$ & $\begin{array}{l}\text { Total } \\
\text { height } \\
(\mathrm{cm})\end{array}$ & $\begin{array}{l}\text { Gain } \\
d_{l} / d_{0}\end{array}$ & $\begin{array}{l}\text { Entrance } \\
\text { diameter } \\
(\mathrm{cm})\end{array}$ & $\begin{array}{l}\text { Total } \\
\text { height } \\
(\mathrm{cm})\end{array}$ & $\begin{array}{r}\text { Gain } \\
d_{l} / d_{0}\end{array}$ & $\begin{array}{l}\text { Entrance } \\
\text { diameter }\end{array}$ & $\begin{array}{l}\text { Total } \\
\text { height }\end{array}$ & Gain \\
\hline 20.00 & 4.26 & 7.60 & 4.26 & 4.27 & 7.62 & 4.27 & 0.22 & 0.18 & 0.22 \\
\hline 30.00 & 4.19 & 6.58 & 4.19 & 4.22 & 6.61 & 4.22 & 0.66 & 0.54 & 0.66 \\
\hline 35.00 & 4.15 & 6.17 & 4.15 & 4.20 & 6.21 & 4.20 & 1.09 & 0.90 & 1.09 \\
\hline 40.00 & 4.11 & 5.80 & 4.11 & 4.18 & 5.88 & 4.18 & 1.76 & 1.46 & 1.76 \\
\hline 45.00 & 4.06 & 5.47 & 4.06 & 4.17 & 5.59 & 4.17 & 2.77 & 2.31 & 2.77 \\
\hline
\end{tabular}

Consider a SolarBrane which utilizes a DTIRC based on MCM with an arc angle of $45^{\circ}$. This SolarBrane achieves a geometrical concentration gain of 4.17. Although a SolarBrane employs only $30 \%$ of the total PV cell when compared to the conventional solar PV system [18], the concentrator is able to focus the sun rays to the PV cell up to 4.17 times, allowing the SolarBrane to theoretically generate 25\% more electricity than the conventional solar PV system having the same area. This does not take into account the power saving from the illumination and ventilation process, as well as from the generation of hot water and space heating.

From this section, it can be concluded that the concentrator in the SolarBrane is capable of reducing the amount of silicon in the design and increasing the geometrical concentration gain at the same time. This helps to increase the performance of the SolarBrane.

\subsection{FINANGIAL ANALYSIS}

It is also useful to investigate the possibility of implementing the optimised SolarBrane in Malaysia. This section analyses the cost of implementing a solar PV system on a typical low-rise house in Malaysia the traditional PV system and the optimised SolarBrane. Then, based on the proposed Feed-In Tariff (FIT) scheme, the performance of the PV is analysed and the cost savings from the 
scheme are calculated. Finally, the payback period and the return on investment of each PV panel type are presented and compared. Similar analysis of implementing the SolarBrane in the United Kingdom was presented in [42].

Malaysia tabled the first draft of the Renewable Energy Act on 15 December 2010, in which an FIT scheme is proposed [43]. The FIT in Malaysia gives great emphasis on solar PV. In Malaysia's case, two meter readings are required, which are the generation and the import meters. All the electricity generated is exported to the national grid. The rate for the amount of electricity generated using the solar PV system, ranges from MYR1.23 to MYR1.78 per $\mathrm{kWh}$ produced [43]. It has a payback period of 21 years and a degression rate of $8 \%$ per year [43].

The cost of installation is calculated, which largely depends on the PV output rating. Next, based on the output rating and the value of solar insolation, the yearly electricity output in $\mathrm{kWh}$ is estimated and is later multiplied with the FIT rate to obtain the annual FIT income. The annual revenue is obtained by subtracting the yearly maintenance cost from the annual FIT income. The total revenue for the whole contract period is calculated by multiplying the annual revenue by the duration of the contract. The total profit generated is equal to the difference between the total revenue and the installation cost. To get the payback period, this figure is generated by dividing the installation cost with the annual revenue while the average annual return on investment is calculated by dividing the total profit with the product of total cost and contract period.

To ease the calculation, a number of assumptions are made: (i) each house uses a $2.50 \mathrm{~kW}$ p solar panel, covering an area of $17 \mathrm{~m}^{2}$ [44]; (ii) the installation cost is paid in full at the beginning of the project - no loan is taken to fund it; (iii) the solar panel maintains $100 \%$ performance during its contract period; (iv) the maintenance cost is $1 \%$ of the capital cost [45], and (v) the calculation will be done for the duration of a contract period of 21 years. The detail results from the calculations are presented in Table 4.

For the installation of a traditional solar PV panel in Malaysia, the cost is estimated to be RM47,800.00. This is based on the MBIPV project result which shows that the average cost of a PV panel is MYR19,120.00 per kWp. The current SolarBrane however only uses $30 \%$ of the PV material [18]; therefore the cost of PV is around MYR8,604.00. Based on the calculation in [46], the cost of implementing the concentrator in the system is estimated to be around MYR65.10 ${ }^{1}$ per square metre, and therefore it equals to MYR1,106.70 for an installation that covers an area of $17.00 \mathrm{~m}^{2}$. Supposing the balance of the system

\footnotetext{
The system in [46] employs the extrusion of CPCs in an area of $0.60 \mathrm{~m}^{2}$, which costs about MYR87.50. To produce a concentrator in an area of $1.00 \mathrm{~m}^{2}$, the cost is estimated to be roughly MYR145.50. Since the size of the DTIRC is less than $45 \%$ of the CPC, the cost of implementing the DTIRC in a $1.00 \mathrm{~m}^{2}$ is estimated to be MYR65.10 per square metre $(£ 1.00$ is equivalence to MYR5.00).
} 
cost remains the same, the total cost of implementing the current design is estimated to be MYR28,830.70.

Now, consider the optimised SolarBrane that uses the DTIRC based on the MCM. From the information in Table 4, if the front surface arc angle is set to be $45^{\circ}$, the increment of the entrance diameter, the total height and the geometrical gain are $2.77 \%, 2.31 \%$ and $2.77 \%$ respectively. If SolarEmpower Ltd. opted to use the optimised concentrator whilst maintaining the same electrical output as the existing concentrator, the amount of PV material used can be reduced by $2.77 \%$ which translates to a cost of MYR8,365.67. The concentrator's volume will be increased by approximately $6.40 \%$, which is roughly around MYR1,177.55. The total cost of implementing the new concentrator is MYR28,663.22. This new design could therefore save about MYR167.48, which contributes to a reduction in total cost of approximately $0.58 \%$ than the current SolarBrane. It can also be seen that by implementing the optimised SolarBrane, a consumer can save about $40.04 \%$ of the total installation cost respectively, when compared to the traditional solar PV system.

Table 4 Financial analysis of implementing a solar PV system on a typical low-rise house in Malaysia

\begin{tabular}{lcrr}
\hline Item & Unit & \multicolumn{1}{c}{$\begin{array}{c}\text { Traditional } \\
\text { Solar PV }\end{array}$} & $\begin{array}{r}\text { Optimised } \\
\text { SolarBrane }\end{array}$ \\
\hline Cost of Implementation & & & \\
PV Material & MYR & $28,680.00$ & $8,365.67$ \\
Concentrator & MYR & 0.00 & $1,177.55$ \\
Balance of System (BOS) & MYR & $19,120.00$ & $19,120.00$ \\
Installation Cost & MYR & $47,800.00$ & $28,663.22$ \\
\hline Average Yearly Solar Insolation & $\mathrm{kWh} / \mathrm{m}^{2}$ & $1,643.00$ & $1,643.00$ \\
Electricity generated from PV panel & $\mathrm{kWh}$ & $4,107.50$ & $4,107.50$ \\
Contract Period & Year & 21.00 & 21.00 \\
\hline Income from FIT Scheme & & & \\
FIT rate per kWh & MYR & 1.78 & 1.78 \\
Generation of Electricity & MYR & $7,311.35$ & $7,311.35$ \\
Maintenance per Year & MYR & 478.00 & 286.63 \\
Total Annual Revenue & MYR & $6,833.35$ & $7,024.72$ \\
Total Revenue After 21 Years & MYR & $143,500.35$ & $147,519.07$ \\
\hline Investment Analysis & & & \\
Total Profit & MYR & $95,700.35$ & $118,855.85$ \\
\hline Payback Period & Year & 7.00 & 4.08 \\
\hline Average Annual Return on Investment & \% & 9.53 & 19.75 \\
\hline
\end{tabular}

Based on the above calculation, it can be seen that the optimised SolarBrane could: (i) reduce the cost per $\mathrm{kWp}$ to about MYR11,500.00 - a reduction of $40 \%$ on the current market price; (ii) generate an extra profit of about MYR23,000.00 
as compared to the traditional solar PV; (iii) recover the installation cost in about 4 years, i.e. 3 years earlier than the traditional solar PV, and (iv) the average annual return of investment is approximately $20 \%$, which is more than double the amount received from the installation of a conventional solar PV.

From the financial analysis, it clearly indicates that the optimised SolarBrane has three advantages; lower installation cost, shorter payback period and higher annual return on investment.

\subsection{CONGLUSIONS}

The main conclusions of this paper are summarized as follows:

1. Solar energy has significant potential in Malaysia. With a growing number of funding resources for R\&D activities, and supported by numerous government policies, solar could become one of the major renewable sources for electricity generation in Malaysia.

2. The recent introduction of the FIT scheme will undoubtedly become the key driver to boost the solar PV industry in Malaysia. However, to eliminate the economic barrier of high installation cost, more R\&D activities need to be carried out on designing a low cost solar PV system. At the moment, most of the solar R\&D activities conducted in Malaysia are considered as basic research [4].

3. One of the alternatives in reducing the cost is to implement a solar concentrator in the solar PV design. An example of a solar PV system utilizing a concentrator is the SolarBrane. SolarBrane could be the chosen BIPV system as compared to traditional solar PVs for the installation in residential and office buildings in Malaysia because of its main advantages; namely, cheaper initial cost due to less PV used and improved performance. A typical PV panel of $2.5 \mathrm{kWhp}$ installed on a house in Malaysia could generate approximately $4,107.50 \mathrm{kWh}$ per year, which is more than the average household electricity requirement in Malaysia [47]. However, SolarBrane not only generates electricity, it is also used for hot water generation, space heating, illumination, ventilation and shade, which further reduces the electricity requirement in a building, making it more desirable [18],[39].

4. An optimised design for the SolarBrane based on the MCM has been explored [39]. Through simulation results, it has been demonstrated that this optimised concentrator design provides slightly higher gain, but produces a slightly larger size. The new optimised concentrator offers a 
lower cost of implementation, shorter payback period and an even higher annual return as compared to the existing design.

5. SolarBrane clearly demonstrates that a solar PV system that incorporates a solar concentrator could maintains or provides better performance than a traditional solar PV system, and helps to reduce the installation cost of the system. With more R\&D activities on the concentrator design, it is possible to develop much cheaper solar PV system in the future.

\section{ACKNOWLEDGMents}

The authors would like to acknowledge the collaboration of SolarEmpower Ltd. for its contribution to this project.

\section{REFERENGES}

[1]. Ahmad, S., Kadir, M. Z. A. A. \& Shafie, S. 2011. Current Perspective of the Renewable Energy Development in Malaysia. Renewable and Sustainable Energy Reviews. 15(2): 897-904.

[2]. Haris, A. H. 2008. MBIPV Project: Catalyzing Local PV Market. Finance E Investment Forum on PV Technology. Kuala Lumpur, Malaysia.

[3]. Amin, N., Lung, C. W. \& Sopian, K. 2009. A Practical Field Study of Various Solar Cells on Their Performance in Malaysia. Renewable Energy. 34(8): 1939-1946.

[4]. Sopian, K., Othman, M. Y., Yatim, B. \& Daud, W. R. W. 2005.Future Directions in Malaysian Environment Friendly Renewable Energy Technologies Research and Development. ISESCO Science and Technology Vision. 1: 30-36.

[5]. Malaysian Science and Technology Information Centre (MASTIC). Available: http://www.mastic.gov.my/ [2011, 18/01/2011].

[6]. Ongkil, M. J. 2010. Keynote Address. Green Energy, Technology \& Innovation Summit $\&$ Green. Energy 2010. Kuala Lumpur, Malaysia.

[7]. Chua, S. C. \& Oh, T. H. 2010. Review on Malaysia's National Energy Developments: Key Policies, Agencies, Programmes and International Involvements. Renewable and Sustainable Energy Reviews. 14(9): 2916-2925.

[8]. Oh, T. H., Pang, S. Y. \& Chua, S. C. 2010. Energy Policy and Alternative Energy in Malaysia: Issues and Challenges for Sustainable Growth. Renewable and Sustainable Energy Reviews. 14(4): 1241-1252.

[9]. Rahman Mohamed, A. \& Lee, K. T. 2006. Energy for Sustainable Development in Malaysia: Energy Policy and Alternative Energy. Energy Policy. 34(15): 2388-2397.

[10]. MBIPV Project. Available: http://www.mbipv.net.my/ [2011, 04/03/2011].

[11]. Abdul Malek, B. 2010. Renewable Energy Development in Malaysia. 34th Expert Group on New and Renewable Energy Technologies (EGNRET). Kuala Lumpur, Malaysia. 1-46.

[12]. Haw, L. C., Sopian, K., Sulaiman, K., Hafidz, M. \& Yahya, M. 2009. Assessment of Public Perception on Photovoltaic Application in Malaysia Urban Residential Areas Using Trudgill's Framework for Analysis. European Journal of Social Sciences. 8(4): 589-603.

[13]. International Energy Agency, 2010. Technology Roadmaps - Solar Photovoltaic Energy. IEA, Paris, France.

[14]. Swanson, R. M. 2000. The Promise of Concentrators. Progress in Photovoltaics: Research and Applications. 8: 93-111. 
[15]. Muhammad-Sukki, F., Ramirez-Iniguez, R., McMeekin, S. G., Stewart, B. G., \& Clive, B. 2010. Solar Concentrators. International Journal of Applied Sciences. 1(1): 1-15.

[16]. Chen, C., Lin, C., Jan, H. \& Yang, Y. 2009. Design Of A Solar Concentrator Combining Paraboloidal And Hyperbolic Mirrors Using Ray Tracing Method. Optics Communications. 282(3): 360-366.

[17]. Sala, G., Pachón, D., \& Antón, I. 2000. Book 1: Classification of PV Concentrators. Test, Rating, and Specification of PV Concentrator Components and Systems, C - Rating Project. Available: http://www.ies-def.upm.es/ies/CRATING/crating.htm [03/05/2010].

[18]. SolarEmpower Ltd. Available: http://www.solarempower.com/ [02/01/2011].

[19]. Miñano J. C. \& Benítez, P., 2008. High Concentration Photovoltaics: Potentials and Challenges. Webinar in Photovoltaic Concentration. USA.

[20]. Mahoney, A. R., Cannon J. E. \& Woodworth, J. R. 1993. Accelerated UV-aging of Acrylic Materials used in PV Concentrator Systems. 23rd IEEE Photovoltaic Specialists Conference. Louisville, Kentucky, USA.

[21]. Terao, A., Mulligan, W. P., Daroczi, S.G., Pujol, O. C., Verlinden, P. J., \& Swanson R. M. 2000. A Mirror-Less Design for Micro-Concentrator Module. 28th IEEE Photovoltaic Specialists Conference. Anchorage, Alaska.

[22]. Chatten, A. J., Barnham, K. W. J., Buxton, B. F., Ekins-Daukes, N. J., \& Malik, M. A. 2003. Quantum Dot Solar Concentrator. Symposium on the Efficient Use of Solar Radiation in Photovoltaics Power Engineering. St. Petersburg, USA.

[23]. Manrique, J. A., 1984. A Compound Parabolic Concentrator. International Communications in Heat and Mass Transfer. 11: 267-273.

[24]. Nordmann, T., \& Clavadetscher, L., 2003. Understanding Temperature Effects on PV System Performance. 3rd World Conference on Photovoltaic Energy Conversion. Osaka, Japan.

[25]. Omubo-Pepple, V. B., Israel-Cookey, C., \& Alaminokuma, G. I., 2009. Effects of Temperature, Solar Flux and Relative Humidity on the Efficient Conversion of Solar Energy to Electricity. European Journal of Scientific Research. 35(2): 173-180.

[26]. Mahinder Singh, B. S. \& Sulaiman, F. 2003. Designing a Solar Thermal Cylindrical Parabolic Trough Concentrator by Simulation. International Rio3 Congress, World Climate and Energy Event. Rio de Janeiro, Brazil, 1-6.

[27]. Kok-Keong Chong, Chee-Woon Wong, Fei-Lu Siaw \& Tiong-Keat Yew, 2010. Solar Flux Distribution Analysis of Non-Imaging Planar Concentrator for the Application in Concentrator Photovoltaic System. 35th IEEE Photovoltaic Specialists Conference. 003013-003018.

[28]. Chen, Y. T., Chong, K. K., Bligh, T. P., Chen, L. C., Yunus, J., Kannan, K. S., Lim, B. H., Lim, C. S., Alias, M. A., Bidin, N., Aliman, O., Salehan, S., Rezan S. A. H., S. A., Tam, C. M. \& Tan, K. K. 2001. Non-Imaging, Focusing Heliostat. Solar Energy. 71(3): 155-164.

[29]. Aliman, O. \& Daut, I., 2007. Rotation-Elevation of Sun Tracking Mode to Gain High Concentration Solar Energy. International Conference on Power Engineering, Energy and Electrical Drives. 551-555.

[30]. Kadir, M. Z. A. A. \& Rafeeu, Y. 2010. A Review On Factors For Maximizing Solar Fraction Under Wet Climate Environment In Malaysia. Renewable and Sustainable Energy Reviews. 14(8): 22432248.

[31]. Abd Malek, N., Hasini, H., Rahman, A. A. \& Nasharuddin Mohd Jaafar, M. 2010. An Improved Solar PV System For Malaysian Rural Electrification Part I: Design And Testing Of Solar PV With Tracker And Reflectors. IEEE Student Conference on Research and Development. 452-457.

[32]. Hossain, E., Muhida, R. \& Ali, A. 2008. Efficiency Improvement Of Solar Cell Using Compound Parabolic Concentrator And Sun Tracking System. IEEE Electric Power Conference. Canada, 1-8.

[33]. Wang, C., Abdul-Rahman, H. \& Rao, S. P. 2010. A New Design of Luminescent Solar Concentrator and Its Trial Run. International Journal of Energy Research. 34(15): 1372-1385.

[34]. Lo, C. K., Lim, Y.S., Tan, S. G. \& Abd Rahman, F. 2010. A New Hybrid Algorithm Using Thermodynamic and Backward Ray-Tracing Approaches for Modeling Luminescent Solar Concentrators. Energies. 3: 1831-1860. 
[35]. Piao, Z. G., Park, J. M., Kim, J. H., Cho, G. B. \& Baek, H. L. 2005. A Study on the Tracking Photovoltaic System By Program Type. Eighth International Conference on Electrical Machines and Systems. 971-973.

[36]. Yizhu Guo, Jianzhong Cha, Wei Liu \& Yaobin Tian 2010. A System Modeling Method For Optimization Of A Single Axis Solar Tracker. 2010 International Conference on Computer Application and System Modeling. V11-30- V11-34.

[37]. Vorobiev, P. Y., Gonzalez-Hernandez, J. \& Vorobiev, Y. V. 2004. Optimization of the Solar Energy Collection in Tracking And Non-Tracking Photovoltaic Solar System. 1st International Conference on Electrical and Electronics Engineering. 310-314.

[38]. Ning, X., Winston, R. and O'Gallagher, J. 1987. Dielectric Totally Internally Reflecting Concentrators. Applied Optics. 26(2): 300-305.

[39]. Clive, B., 2005. Photovoltaic Cell Apparatus. Patent Number WO/2010/026415.

[40]. Muhammad-Sukki, F., Ramirez-Iniguez, R., McMeekin, S. G., Stewart, B. G., \& Clive, B. 2010. Optimised Dielectric Totally Internally Reflecting Concentrator for the Solar Photonic Optoelectronic Transformer System: Maximum Concentration Method. 14th International Conference on Knowledge Based and Intelligent Information E Engineering Systems. Cardiff, UK, Part IV, LNAI 6279, 633-641.

[41]. Muhammad-Sukki, F., Ramirez-Iniguez, R., McMeekin, S. G., Stewart, B. G., \& Clive, B. 2011. Optimised Concentrator for the Solar Photonic Optoelectronic Transformer System: First Optimisation Stage. 2nd International Conference on Harnessing Technology. Muscat, Oman, Paper No. 41, 1-7.

[42]. Muhammad-Sukki, F., Ramirez-Iniguez, R., McMeekin, S. G., Stewart, B. G., \& Clive, B. 2011. Optimisation of Concentrator in the Solar Photonic Optoelectronic Transformer: Comparison of Geometrical Performance and Cost of Implementation. International Conference on Renewable Energies and Power Quality. Las Palmas de Gran Canaria, Spain, Paper No. 436, 1-6.

[43]. Malaysian Government, 2010. Renewable Energy Bill. Kuala Lumpur, Malaysia.

[44]. Solarcentury. Available http://www.solarcentury.co.uk/ [28/02/2011].

[45]. IEA, 2010. Technology Roadmaps - Solar Photovoltaic Energy. Paris, France.

[46]. Eames, P. C., Zacharopoulos, A., McLarnon, D., Hyde, T. J., \& Norton, B., 2000. Development and Experimental Characterisation of Low Cost Façade Integrated Concentrator Photovoltaics. Chartered Institution of Building Services Engineers Conference. Dublin, Ireland.

[47]. Energy Commission, 2010. Interim Report on the Performance of the Electricity Supply Services in Malaysia (for the first half year of 2010). Putrajaya, Malaysia. 